\title{
Determination of the Prevalence of Postpartum Depression and Risk Factors Among Postpartum Patients at a Tertiary Government Urban Hospital Using the Edinburgh Postnatal Depression Scale- Filipino Translation (EPDS-F): A Cross-Sectional Study
}

Maria Carmina Lorenzana Santiago ( $\square$ mindy.santiago@gmail.com )

Philippine General Hospital https://orcid.org/0000-0003-2624-9114

Maria Antonia Esteban Habana

University of the Philippines-Philippine General Hospital

Research article

Keywords: Edinburgh Postnatal Depression Scale, Edinburgh Postnatal Depression Scale-Filipino Translation, postnatal depression, postpartum depression, Psychiatric Status Rating Scales

Posted Date: June 15th, 2020

DOI: https://doi.org/10.21203/rs.3.rs-34244/v1

License: (c) (1) This work is licensed under a Creative Commons Attribution 4.0 International License. Read Full License 
Determination of the Prevalence of Postpartum Depression and Risk Factors Among Postpartum Patients at a Tertiary Government Urban Hospital Using the Edinburgh Postnatal Depression Scale-Filipino Translation (EPDS-F):

A Cross-Sectional Study

\author{
Maria Carmina L. Santiago, M.D. (corresponding author) \\ Department of Obstetrics and Gynecology, University of the Philippines- \\ Philippine General Hospital \\ Email:mindy.santiago@gmail.com \\ Maria Antonia E. Habana, M.D. M.Sc. \\ Department of Obstetrics and Gynecology, University of the Philippines- \\ Philippine General Hospital
}




\section{ABSTRACT}

\section{Background}

Postpartum depression (PPD) occurs in $10-15 \%$ of deliveries worldwide. Unfortunately there is a dearth of local studies on its exact prevalence.

\section{Method}

This cross-sectional study aimed to determine the prevalence of and risk factors for PPD among postpartum patients at a tertiary government hospital using the Edinburgh Postnatal Depression Scale-Filipino Translation (EPDS-F), a 10point questionnaire translated into Filipino and previously validated. Four hundred patients within 8 weeks postpartum were recruited and their EPDS-F scores and sociodemographic, medical and personal history, and delivery and perinatal outcome data were obtained.

\section{Results}

The overall prevalence of PPD was $14.5 \%$, which is within the known worldwide prevalence. Among those that had family incomes below PhP10,000, the proportion that had high EPDS-F scores was $68.8 \%$, while those that had low EPDS-F scores was $48.8 \%$ (significant at $p=0.001$ ). Among those that finished below tertiary education, the proportion that had high EPDS-F scores was $81 \%$, while those that had low EPDS-F scores was $59.9 \%$ (significant at $p=0.002$ ). Among those who delivered vaginally, 62.1\% had high EPDS-F scores vs $44.2 \%$ low EPDS-F $(p=0.03)$. Of those that had epidural anesthesia (106 or 26.5\%), 44.8\% had high EPDS scores and 26.0\% had low EPDS-F scores 
$(p=0.04)$. Regression analysis showed that having an abdominal delivery is correlated with a lower EPDS-F score by $0.87 \%$ by logistic regression and 0.46 $\%$ by probit regression. Having a higher educational attainment and monthly income are associated with a lower EPDS-F score by regression analysis.

\section{Conclusions}

The prevalence may be skewed because a tertiary government institution caters to delicate pregnancies and those in low socioeconomic brackets. It may be worthwhile to compare responses from a public versus a private institution, also urban versus rural areas. It would be interesting also to evaluate the mode of delivery variable and how exactly it correlates with the development of postpartum depression.

KEYWORDS: Edinburgh Postnatal Depression Scale, Edinburgh Postnatal Depression Scale-Filipino Translation, postnatal depression, postpartum depression, Psychiatric Status Rating Scales 


\section{BACKGROUND}

Postpartum depression (PPD) occurs in $10-15 \%$ of all deliveries worldwide1. Unfortunately there is a dearth of local studies on the exact prevalence of this disorder. It is estimated that there were 126,826 cases of PPD in the Philippines in 20042. However very little research has been done on the development and prevention of this disorder, despite the fact that depression that has onset in the postpartum period has been shown to lead to persistence of depression after one year and even behavioral problems in the child3.

Among patients with PPD, approximately 50 percent experience symptoms before or during pregnancy4. In a prospective study of 546 pregnant and postpartum women and diagnosed with postnatal depression, 20 percent had symptom onset prepregnancy, 38 percent antepartum, and 42 percent postpartum5. And in those whose symptoms begin after delivery, majority seem to have onset within the first few months postpartum6. A retrospective study of women with postpartum onset of major depression $(n=116)$ found that onset occurred as follows7.

-Postpartum month $1-54$ percent
-Postpartum month 2 to $4-40$ percent
-Postpartum month 5 to $12-6$ percent

The Edinburgh Postnatal Depression Scale (EPDS) is a ten-item questionnaire used to identify women who have postpartum depression. It was designed by Cox et al in 19878; each item is assigned a score 0 to 3 and the test yields a 
score of 0 to 30 . The items ask about symptoms that the patient felt in the last week and the patient rates her mood, feelings of anxiety, guilt, anhedonia, selfharm, and suicidal ideation. Women with a score of 10-12 are said to be at risk for PPD.

The EPDS may be used within eight weeks postpartum. This tool was translated into the Filipino and validated in a 2005 study9 (Edinburgh Postnatal Depression Scale-Filipino Translation or EPDS-F). It is proposed that this tool be used to determine the prevalence of postpartum depression in Filipinos and at the same time, determine the risk factors for this.

\section{Critical review of past researches concerning research questions}

The Diagnostic and Statistical Manual of Mental Disorders, 5th edition10 defines postpartum depression as a major depressive episode with an onset in pregnancy or within four weeks of delivery. In the Philippines, there were an estimated 126,826 cases of postpartum depression in 2004 , but a dearth of local studies on the disorder2. The late Senator Miriam Defensor-Santiago authored the Postpartum Depression Research Act in 2007, for the 13th Congress2. This act aimed to provide research on understanding the causes of, and to find a cure for, postpartum depression and psychosis. If approved, resources would be allocated for activities that include basic research concerning the etiology and causes of the conditions, epidemiological studies to address the frequency and natural history of the conditions, development of improved diagnostic techniques, clinical research for the development and 
evaluation of new treatments, and information and education programs for health care professionals and the public. However, this bill is still currently pending in the senate.

A study conducted by De Chavez11 at a tertiary hospital in Dasmariñas, Cavite, Philippines aimed to determine the prevalence of postpartum depression among postpartum patients. The authors determined the proportion of mothers experiencing postpartum depression on the basis of the following sociodemographic factors: age, marital status, employment status, manner of delivery, parity, age of gestation upon delivery, gender of the newborn and breastfeeding status. They used the Edinburgh Postnatal Depression Scale (EPDS) and found that of 115 patients, 89 had an EPDS score below 10 points corresponding to $77.39 \%$ of the total population studied, while 26 participants had a score of at least 10 points corresponding to $22.61 \%$. There were 9 respondents who scored at least 1 point in question number 10 pertaining to $7.83 \%$ of the population. The prevalence of postpartum depression among them was $22.61 \%$.

The development of postpartum depression is multifactorial. A meta-analysis by Beck 12 of 84 studies published in the decade of the 1990s was conducted to determine the magnitude of the relationships between postpartum depression and various risk factors. Thirteen significant predictors of postpartum depression were revealed: Prenatal depression, self-esteem, childcare stress, prenatal anxiety, life stress, social support, marital relationship, history of 
previous depression, infant temperament, maternity blues, marital status, socioeconomic status, and unplanned/unwanted pregnancy. Ten of these 13 risk factors had moderate effect sizes while three predictors had small effect sizes.

A study by Miller13 demonstrated that the following risk factors are strong predictors of postpartum depression: depression or anxiety during pregnancy, stressful recent life events, poor social support and a previous history of depression. Moderate predictors of postpartum depression are childcare stress, low self-esteem, maternal neuroticism and difficult infant temperament. Small predictors include obstetric and pregnancy complications, negative cognitive attributions, single marital status, poor relationship with partner, and lower socioeconomic status including income. No relationship was found for ethnicity, maternal age, level of education, parity, or gender of child.

The lack of research on this disorder is alarming, because of the burden of the disease not only on the mother but on the child as well. Studies show that 25 $\%$ of women with postpartum depression will be depressed 1 year later. And as the duration of depression increases, so too do the number of sequelae and their severity. Also, maternal depression during the first weeks and months after delivery can lead to insecure attachment and later behavioral problems in the child3. 
Philipps14 conducted a 4.5-year prospective study of postpartum depression in 70 women. He found that women who had experienced a postpartum depression were predicted to be at increased risk for subsequent depression and poor adjustment of their child. Postpartum depression was directly related to subsequent depression but not child problems. Later depression was related to child problems at $4 \frac{1}{2} \mathrm{yrs}$. It was concluded that postpartum depression may increase risk for later maternal depression and in turn increases risk for child behavior problems. Intervening with women who have experienced a postpartum depression may reduce likelihood of future depressions and child behavior problems.

Early recognition is one of the most difficult challenges with postpartum depression because of how covertly it is suffered. Dennis15 conducted a systematic review on help-seeking behavior among women diagnosed with postpartum depression. Forty articles were reviewed, and it was found that a common help-seeking barrier was women's inability to disclose their feelings, which was often reinforced by family members and health professionals' reluctance to respond to the mothers' emotional and practical needs. The lack of knowledge about postpartum depression or the acceptance of myths was a significant help-seeking barrier and rendered mothers unable to recognize the symptoms of depression.

According to the American College of Obstetricians and Gynecologists, there is currently insufficient evidence to make a recommendation for routine 
depression screening, either during or after pregnancy 16. At Parkland Hospital, all women are asked about depression and domestic violence at their first prenatal visit. They are also screened again during their first postpartum visit using the Edinburgh Postnatal Depression Scale (EPDS). In an analysis 17 of more than 17,000 of these questionnaires, $6 \%$ had scores that indicated either minor or major depressive symptoms. Twelve of these 1106 women also had thoughts of self-harm.

The Edinburgh Postnatal Depression Scale (EPDS), a 10-item questionnaire that was developed in Scottish health centers in Edinburgh and Livingston to identify women who have PPD8. Items of the scale correspond to various clinical depression symptoms, such as guilt feeling, sleep disturbance, low energy, anhedonia, and suicidal ideation. The EPDS may be used within 8 weeks postpartum and it also can be applied for depression screening during pregnancy.

The EPDS was validated among 191 women 1-6 weeks postpartum at the Philippine General Hospital9. They answered the Edinburgh Postnatal Depression Scale-Filipino Translation (EPDS-F) and underwent DSM-IV based psychiatric interview. They found that sensitivity was $71.4 \%$, specificity was $84.2 \%$, positive predictive value was $26.3 \%$ and negative predictive value was $97.4 \%$. Their results confirm the validity of EPDS-F among postpartum Filipinas. This tool can therefore be used to determine the prevalence of the disease as well as the risk factors for its development. 


\section{Significance of the study}

Currently there are only a few available local studies on postpartum depression. It is fortunate that we have available the Edinburgh Postnatal Depression Scale that has been translated into Filipino and validated in a 2005 study 13 . This study also recommended that future research would have a larger sample size in order to obtain a more accurate estimate of prevalence of PPD in the country.

Participation in the study may diagnose existing postpartum depression or identify patients at risk for its development. The results may be used for further research on postpartum depression and will thus also be beneficial for future generations of postpartum women. Also, answering the questionnaire will serve as screening for postpartum depression and should postpartum depression be detected, it can be managed immediately with referral to a psychiatrist.

\section{OBJECTIVES}

General objective: To determine the prevalence of and risk factors for the development of postpartum depression among postpartum patients at a tertiary government hospital using the Edinburgh Postnatal Depression Scale-Filipino Translation (EPDS-F).

\section{Specific objectives:}

1. To describe the socio-demographic profile of the patients diagnosed with postpartum depression. 
2. To determine the prevalence of postpartum depression among postpartum patients at a tertiary government hospital.

3. To determine the risk factors for developing postpartum depression.

\section{METHODS}

\section{Study design}

A cross-sectional study was conducted among postpartum patients at a tertiary government hospital using the Edinburgh Postnatal Depression Scale-Filipino Translation (EPDS-F).

\section{Selection of subjects and sample size calculation}

Based on the Annual Perinatology and Neonatology Statistics done at this tertiary government hospital, there were 5126 deliveries in the year 2016 . This number was used as the population size. The worldwide estimated prevalence of depression among recently delivered women at $10-15 \%$, and the prevalence found by Torres study $7.3 \%$, though with a small sample size of 191 . The prevalence was thus set at $50 \%$ and the confidence level at $95 \%$, the computed sample size was 357. Ten percent was added to account for incomplete information and losses; hence the sample size was set at 400 .

Inclusion criteria: Patients at least 18 years of age who have delivered a fetus of more than 20 weeks age of gestation, weighing more than 500 grams, within the last 8 weeks, whether vaginal or abdominal delivery, term or preterm, alive or dead. 


\section{Exclusion criteria:}

- Cases of abortion, ectopic pregnancy, hydatidiform mole.

- Those who have previously been diagnosed with a depressive disorder.

- Those who cannot speak Filipino.

\section{Data collection}

In 2016, the tertiary government hospital had a total of 5126 deliveries. It is thus an ideal setting for research on postpartum women. It was decided that the data gathering be done on postpartum patients on follow up at the outpatient department instead of immediately postpartum to allow for adequate time for the patient to settle at home after the delivery. Also, postpartum depression typically manifests within the first 1-3 weeks postpartum, and the first postpartum visit is usually scheduled within the first 1-2 weeks after delivery.

The study was conducted at a tertiary government hospital of Obstetrics and Gynecology Outpatient Department (OPD) where postpartum patients come for their follow up. An average of 5 to 10 postpartum patients are seen at the OPD per day. A research assistant conducted the data collection over 5 months from April to October 2018. Four hundred participants were recruited and answered the self-administered questionnaire while waiting for their turn for checkup.

The Edinburgh Postnatal Depression Scale (APPENDIX A) was previously translated into the Filipino and validated. The Edinburgh Postnatal Depression 
Scale-Filipino Translation (APPENDIX B) were answered by postpartum patients on follow up at the outpatient clinic. Each item of the EPDS is assigned a score 0 to 3 give a total score between 0 to 30 . Women with a score of 10 are classified as at risk for development of PPD. For sociodemographic data, there was a separate sociodemographic data sheet in Filipino (APPENDIX C, English translation also provided, APPENDIX D, and other pertinent information (data on the delivery, course of hospital stay, among others) were retrieved from the patient's charts (APPENDIX E), permission for which was included in the informed consent) (APPENDIX F in Filipino, APPENDIX G in English).

\section{Data processing and analysis}

Analysis of the data from the actual survey included computation of prevalence and descriptive statistics to calculate the risk factors based on patient demographics and profile. Chi-square test was used to determine the association.

Once the data was extracted by the investigator from the charts of the patients, all the information was manually entered into an electronic spreadsheet for data processing and analysis. The socio-demographic and clinical variables were presented in frequencies and percentages for categorical variables such as sex, marital status, mode of delivery and reasons for removal; or mean, standard deviation or range for continuous variables such as age, gravidity and parity.

For the general objective, the prevalence of PPD were presented as frequency and percentage, the denominator being the total number of subjects 
included in the study. A 95\% confidence interval of the prevalence rate was computed.

For the first specific objective, independent t-test was used to compare variables such as age, number of pregnancies and children between those who were noted by the scale to have PPD and otherwise. Chi-square test of association was used to determine differences across categorical variables such as marital status, employment status, presence of co-morbidities, and use of contraception in terms of PPD status from the EPDS-F.

For the second specific objective, z-test of proportions was done to compare the prevalence and established risk factors in Filipinos to the general population of postpartum women if there are available data for the comparison.

Regression analysis was performed for all the variables, specifically multivariate regression estimated through ordinary least squares (OLS).

Analysis was performed using the software Stata 13. The level of significance for all sets of analysis was put at 0.05 using two-tailed comparisons.

\section{RESULTS}

Of the 400 participants, 58 had EPDS-F scores 10 and higher, classifying them as at risk for developing postpartum depression. All 58 were referred to Psychiatry for further evaluation and management.

The overall prevalence of PPD was thus computed to be at $14.5 \%$. This is within the known worldwide prevalence of $10-15 \% 1$ but higher than in the local study 
done by Torres 13 in 2005 (7.3\% in 191 women). The mean EPDS-F score of the depressed group was 13.1, as opposed to 3.0 in the non-depressed group. Tables 1, 2, and 3 show the breakdown and percentages of the sociodemographic variables, medical and personal history variables, and deliveryrelated and perinatal outcome variables, respectively.

Socio-Demographic Variables (Table 1)

\begin{tabular}{|c|c|c|c|}
\hline Characteristics & $\begin{array}{c}\text { High EPDS score } \\
\mathrm{N}=58(\%)\end{array}$ & $\begin{array}{c}\text { Low EPDS Score } \\
\mathrm{N}=342(\%)\end{array}$ & $p$-value \\
\hline Age in years & $28.3 \pm 5.4$ & $28.8 \pm 6.4$ & \\
\hline $\begin{array}{l}\text { Obstetric score } \\
\text { Multigravid } \\
\text { Primigravid }\end{array}$ & $\begin{array}{l}43.0(74.1) \\
15.0(25.9)\end{array}$ & $\begin{array}{l}231.0(67.5) \\
111.0(32.5)\end{array}$ & $\begin{array}{l}0.70 \\
0.20\end{array}$ \\
\hline $\begin{array}{l}\text { Marital status } \\
\text { Single } \\
\text { Married } \\
\text { Live in partner }\end{array}$ & $\begin{array}{l}33.0(56.8) \\
19.0(32.7) \\
6.0(10.3)\end{array}$ & $\begin{array}{l}191.0(55.8) \\
129.0(37.7) \\
21.0(6.1)\end{array}$ & $\begin{array}{l}0.46 \\
0.66 \\
0.36\end{array}$ \\
\hline $\begin{array}{l}\text { Highest level of education } \\
\text { Elementary } \\
\text { Secondary } \\
{ }_{\star}^{*} \text { Elementary and secondary } \\
\text { Tertiary }\end{array}$ & $\begin{array}{l}5.0(8.6) \\
42.0(72.4) \\
* * 47.0(81.0) \\
11.0(18.9) \\
\end{array}$ & $\begin{array}{l}14.0(4.1) \\
191.0(55.8) \\
* \star 205.0(59.9) \\
137.0(40.1)\end{array}$ & $\begin{array}{l}0.35 \\
0.02^{*} \\
* * 0.002^{*} \\
0.92\end{array}$ \\
\hline $\begin{array}{l}\text { Employment status } \\
\text { Employed } \\
\text { Unemployed }\end{array}$ & $\begin{array}{l}13.0(22.4) \\
45.0(77.6) \\
\end{array}$ & $\begin{array}{l}91.0(26.6) \\
251.0(73.3)\end{array}$ & $\begin{array}{l}0.63 \\
0.28\end{array}$ \\
\hline $\begin{array}{c}\text { Monthly family income } \\
<5,000 \\
5,000-10,000 \\
{ }^{* *}<10,000 \\
10,000-15,000 \\
15,000-20,000 \\
\geq 20,000\end{array}$ & $\begin{array}{l}18.0(31.0) \\
22.0(37.8) \\
\star * 40.0(68.8) \\
12.0(20.7) \\
4.0(6.9) \\
2.0(3.4)\end{array}$ & $\begin{array}{l}54.0(15.8) \\
110.0(32.2) \\
\star * 164.0(48.0) \\
109.0(31.8) \\
38.0(11.1) \\
31.0(9.1)\end{array}$ & $\begin{array}{l}0.08^{\star} \\
0.30 \\
* * 0.001^{*} \\
0.79 \\
0.60 \\
0.61\end{array}$ \\
\hline
\end{tabular}

The mean age of all 400 respondents was 28.7 ( $S D \pm 6.2$ ). Mean age for the high EPDS-F score group was $28.3(\mathrm{SD} \pm 5.4)$ and 28.8 (SD \pm 6.4$)$ for the low EPDS-F score with no significant difference between groups. The majority or 
$68.5 \%$ of participants were multigravids (high EPDS-F $74 \%$ vs low EPDS-F $67.5 \%$. Majority or $56 \%$ are single (high EPDS $56.8 \%$ vs low EPDS $55.8 \%$ ), and unemployed (high EPDS-F 77.5\% vs low EPDS-F 73.3\%). The majority of those with high EPDS-F scores had a monthly family income below PhP10,000 or USD198 (high EPDS-F $69 \%$ vs low EPDS-F 48\%). For education, $58 \%$ of respondents completed secondary education (high EPDS-F $72.4 \%$ vs low EPDS-F 55.8\%). Of those who completed college, $18.9 \%$ had high EPDS-F scores vs $40 \%$ with low EPDS-F scores.

Of these, the only variables which reached statistical significance $(p<0.05)$ were the monthly family income below PhP10,000 and completed secondary education. So these were further analyzed to include those with family income less than PhP5,000 or USD99, and those who completed only elementary education. Among those that had family monthly incomes below PhP10,000, the proportion that had high EPDS-F scores was $68.8 \%$, while those that had low EPDS-F scores was $48.8 \%$. This was significantly different at $\mathrm{p}=0.001$. Similarly, among those that finished below tertiary education or only elementary or secondary, the proportion that had high EPDS-F scores was $81 \%$, while those that had low EPDS scores was $59.9 \%$. This was significantly at $p=0.002$. 
Medical and Personal History Variables (Table 2)

\begin{tabular}{|c|c|c|c|}
\hline Characteristics & $\begin{array}{l}\text { High EPDS score } \\
\mathrm{N}=58(\%)\end{array}$ & $\begin{array}{l}\text { Low EPDS Score } \\
\mathrm{N}=342(\%)\end{array}$ & p-value \\
\hline $\begin{array}{l}\text { Personal history of } \\
\text { psychiatric condition } \\
\text { Yes } \\
\text { No }\end{array}$ & 0.0 & 1.0 & - \\
\hline $\begin{array}{l}\text { Family history of psychiatric } \\
\text { condition } \\
\text { Yes } \\
\text { No }\end{array}$ & $\begin{array}{l}5.0(8.6) \\
53(91.4)\end{array}$ & $\begin{array}{l}28.0(8.2) \\
314(91.8)\end{array}$ & $\begin{array}{l}0.49 \\
0.54\end{array}$ \\
\hline $\begin{array}{l}\text { Presence of medical } \\
\text { comorbidities } \\
\text { None } \\
\text { Hypertension } \\
\text { Diabetes mellitus } \\
\text { Heart disease } \\
\text { Thyroid disease } \\
\text { Bronchial asthma } \\
\text { Others }\end{array}$ & $\begin{array}{l}42(72.4) \\
5.0(8.6) \\
5.0(8.6) \\
2.0(3.4) \\
1.0(1.7) \\
1.0(1.7) \\
2.0(3.4)\end{array}$ & $\begin{array}{l}259.0(75.5) \\
23.0(6.7) \\
8.0(2.3) \\
4.0(1.2) \\
21.0(6.1) \\
16.0(4.7) \\
11.0(3.2)\end{array}$ & $\begin{array}{l}0.68 \\
0.44 \\
0.30 \\
0.42 \\
0.57 \\
0.55 \\
0.49\end{array}$ \\
\hline $\begin{array}{l}\text { Currently smoking } \\
\text { Yes } \\
\text { No }\end{array}$ & $\begin{array}{l}0.0(0.0) \\
58.0(100.0)\end{array}$ & $\begin{array}{l}3.0(0.9) \\
339.0(99.1) \\
\end{array}$ & $-\overline{0}$ \\
\hline $\begin{array}{l}\text { Currently with alcohol intake } \\
\text { Yes } \\
\text { No }\end{array}$ & $\begin{array}{l}4.0(6.9) \\
54.0(93.1)\end{array}$ & $\begin{array}{l}19.0(5.5) \\
323.0(94.4)\end{array}$ & $\begin{array}{l}0.46 \\
0.65 \\
\end{array}$ \\
\hline $\begin{array}{l}\text { History of physical abuse } \\
\text { Yes } \\
\text { No }\end{array}$ & $\begin{array}{l}0.0(0.0) \\
58.0(100.0)\end{array}$ & $\begin{array}{l}7.0(2.0) \\
335.0(98.0)\end{array}$ & $\overline{-}-14$ \\
\hline $\begin{array}{l}\text { History of sexual abuse } \\
\text { Yes } \\
\text { No }\end{array}$ & $\begin{array}{l}1.0(1.7) \\
57.0(98.3)\end{array}$ & $\begin{array}{l}4.0(1.2) \\
338.0(98.8)\end{array}$ & $\begin{array}{l}0.48 \\
0.64\end{array}$ \\
\hline $\begin{array}{l}\text { Status of child } \\
\text { Alive } \\
\text { Died }\end{array}$ & $\begin{array}{l}58.0(100.0) \\
0.0(0.0)\end{array}$ & $\begin{array}{l}340.0(99.4) \\
2.0(0.6)\end{array}$ & $\begin{array}{l}0.28 \\
-\end{array}$ \\
\hline $\begin{array}{l}\text { Child with congenital illness } \\
\text { Yes } \\
\text { No }\end{array}$ & $\begin{array}{l}5.0(8.6) \\
53.0(91.4)\end{array}$ & $\begin{array}{l}16.0(4.7) \\
326.0(95.9)\end{array}$ & $\begin{array}{l}0.37 \\
0.92\end{array}$ \\
\hline
\end{tabular}

Only 1 of the 400 respondents reported a personal history of mental illness, and she had a low EPDS-F score. Thirty-three participants reported having mental illness in the family (high EPDS-F $8.6 \%$ vs low EPDS-F 8.2). Seven 
respondents had a history of physical abuse, and all of them had low EPDS-F scores. Five had a history of sexual abuse of which one had a high EPDS-F score (1.7\% vs Low EPDS-F 1.2\%). Three respondents admitted to smoking, all had a low EPDS-F score while 23 were alcohol consumers (high EPDS-F-F $6.9 \%$ vs low EPDS $5.5 \%$. Ninety-nine patients or 24.8 percent had medical comorbidities-28 hypertensive (high EPDS-F 8.6\% vs low EPDS-F 6.7\%), 13 diabetics (high EPDS-F 8.6\% vs low EPDS-F 2.3\%), 6 with heart disease (high EPDS-F 3.4\% vs low EPDS-F 1.2\%), 22 with thyroid disease (high EPDS-F $1.7 \%$ vs low EPDS-F $6.1 \%$ ), 17 with bronchial asthma (high EPDS-F $1.7 \%$ vs low EPDS-F 4.7\%), and 13 with other illnesses (high EPDS-F 3.4\% vs low EPDS-F 3.2\%). None of these were significantly different. Among those with children with congenital illness, majority had high EPDS-F scores (8.6\%) as opposed to low EPDS-F scores (4.7\%). All were live births. None of the medical and personal history variables were significantly different between the high and low EPDS score groups. 
Delivery-related and Perinatal Outcome Variables (Table 3)

\begin{tabular}{|c|c|c|c|}
\hline Characteristics & $\begin{array}{l}\text { High EPDS } \\
\text { score } \\
\mathrm{N}=58(\%)\end{array}$ & $\begin{array}{c}\text { Low EPDS Score } \\
\mathrm{N}=342(\%)\end{array}$ & p-value \\
\hline $\begin{array}{l}\text { Planned pregnancy? } \\
\text { Yes } \\
\text { No }\end{array}$ & $\begin{array}{l}22.0(37.9) \\
36.0(62.1)\end{array}$ & $\begin{array}{l}137.0(40.1) \\
205.0(59.9)\end{array}$ & $\begin{array}{l}0.58 \\
0.40\end{array}$ \\
\hline $\begin{array}{l}\text { Mode of delivery } \\
\text { Vaginal } \\
\text { Abdominal }\end{array}$ & $\begin{array}{l}36.0(62.1) \\
22.0(37.9)\end{array}$ & $\begin{array}{l}151(44.2) \\
191(55.8)\end{array}$ & $\begin{array}{l}0.03^{*} \\
0.94\end{array}$ \\
\hline $\begin{array}{l}\text { Induction of labor } \\
\text { Yes } \\
\text { No }\end{array}$ & $\begin{array}{l}24.0(66.7) \\
12.0(33.3)\end{array}$ & $\begin{array}{l}89.0(58.9) \\
62.0(41.1)\end{array}$ & $\begin{array}{l}0.25 \\
0.69\end{array}$ \\
\hline $\begin{array}{l}\text { Use of epidural? } \\
\text { Yes } \\
\text { No }\end{array}$ & $\begin{array}{l}26.0(72.2) \\
10.0(27.8)\end{array}$ & $\begin{array}{l}80.0(53.0) \\
71.0(47.0)\end{array}$ & $\begin{array}{l}0.04^{*} \\
0.87\end{array}$ \\
\hline $\begin{array}{l}\text { Hours of labor } \\
<8 \text { hours } \\
\geq 8 \text { hours }\end{array}$ & $\begin{array}{l}22.0(61.1) \\
1.0(0.7)\end{array}$ & $\begin{array}{l}79.0(52.3) \\
1.0(0.7)\end{array}$ & $\begin{array}{l}0.23 \\
0.50\end{array}$ \\
\hline $\begin{array}{l}\text { Obstetric complications } \\
\text { Yes } \\
\text { No }\end{array}$ & $\begin{array}{l}4.0(11.1) \\
32.0(88.9)\end{array}$ & $\begin{array}{l}19.0(12.6) \\
132.0(87.4)\end{array}$ & $\begin{array}{l}0.53 \\
0.41\end{array}$ \\
\hline $\begin{array}{l}\text { Child with congenital illness } \\
\text { Yes } \\
\text { No }\end{array}$ & $\begin{array}{l}5.0(8.6) \\
53.0(91.4)\end{array}$ & $\begin{array}{l}16.0(4.7) \\
326(95.9)\end{array}$ & $\begin{array}{l}0.37 \\
0.92\end{array}$ \\
\hline $\begin{array}{l}\text { Breastfeeding } \\
\text { Yes } \\
\text { No }\end{array}$ & $\begin{array}{l}55.0(94.8) \\
3.0(5.2)\end{array}$ & $\begin{array}{l}323.0(94.4) \\
19.0(5.6)\end{array}$ & $\begin{array}{l}0.45 \\
0.51\end{array}$ \\
\hline
\end{tabular}

A total of 159 or $39.8 \%$ had unplanned pregnancies. Thirty-eight percent had high EPDS-F scores vs $40 \%$ with low EPDS-F scores. Majority were breastfeeding (94.8\% high EPDS vs $94.4 \%$ low EPDS-F). One hundred eightyseven (46.8\%) delivered vaginally (high EPDS-F $62.1 \%$ vs low EPDS-F $44.2 \%)$. Those who underwent vaginal delivery were further analyzed according to whether or not they underwent labor induction, whether or not epidural anesthesia was given, and the duration of their labor (less than or more than 8 hours. Of those that had labor induction, $24(41.4 \%)$ were in the high 
EPDS-F score group vs 89 (26\%) in the low EPDS-F score group. Majority had labor lasting less than 8 hours (61.1\% high EPDS-F vs 52.3\% low EPDS-F). Of those that had epidural anesthesia (106 or $26.5 \%$ ), $44.8 \%$ had high EPDS-F scores and $26.0 \%$ had low EPDS-F scores. Twenty-three patients (5.8\%) developed obstetric complications. Four had wound dehiscence while 20 had surgical site infections. Among these, 4 were had high EPDS-F scores (6.9\%) and $19(5.6 \%)$ had low EPDS-F scores. Only 2 reported that their children had expired, both of whom had low EPDS scores. Among those with children with congenital illness, more mothers had high EPDS scores (8.6\% vs $4.7 \%$ low EPDS scores).

Among these, only the mode of delivery and use of epidural anesthesia were statistically significant. Among those who underwent vaginal delivery, $62.1 \%$ had high EPDS scores vs $44.2 \%$ low EPDS-F $(p=0.03)$. Of those that had epidural anesthesia (106 or $26.5 \%$ ), $44.8 \%$ had high EPDS scores and $26.0 \%$ had low EPDS scores $(p=0.04)$. 


\section{Regression Analysis (Table 4)}

Method

\section{Dependent Variable}

Independent Variables

$\mathrm{C}$

Age

Child with Congenital IIIness

Medical Comorbidities

Obstetric Complications

Mode of Delivery

Education

Employment

1.73

[1.47]

$-1.60$

$[-3.42]^{\star *}$

2.17

[1.81]

$-0.06$

$-0.02$

$[-0.83]$

1.16

[1.08]

0.56

[0.95]

PPD

0.80

[1.41]

$-0.04$

[-0.43]

$-0.01$

[-0.62]

0.44

[1.37]

$-0.03$

[-0.53]

0.74

[1.20]

0.40

[1.20]

$-0.46$

$[-2.76]^{\star *}$

$[-2.72]^{\text {* }}$

$-1.23$

$[-3.39]^{\star \star}$

$-0.69$

$[-2.39]^{\star}$

$-0.4$

$[-2.54]^{*}$

$-0.40$

$-0.26$

$-0.13$

[-0.72]

[-0.69]

[-0.65]
History of Family Mental
Illness

History of Family Mental
Illness

Family Income

$\begin{array}{ccc}0.51 & 0.26 & 0.14 \\ {[0.67]} & {[0.49]} & {[0.49]}\end{array}$

$$
-0.41
$$

$-0.44$

$-0.23$

$[-2.10]^{*}$

$[-2.84]^{* *}$

$[-2.84]^{\star *}$

OB Score

0.48

0.22

[1.25]

[1.07]

0.04

$-0.01$

\begin{tabular}{c} 
Planned Pregnancy \\
\hline \hline Observations: \\
R-squared:
\end{tabular}

0.43

[0.14]

[-0.05]

400

400

400

0.09

0.09

0.09

t-Statistic in brackets. Significance at 1 percent $\left({ }^{* * *}\right), 5$ percent $\left(^{* \star}\right)$, and 10 percent $\left({ }^{*}\right)$ levels. 
Regression analysis was performed for all the variables. Using the multivariate regression estimated through ordinary least squares (OLS), the mode of delivery, level of education, and monthly family income were found to be significant in determining the EPDS-F score. Women who underwent abdominal delivery had a lower EPDS-F score on average by 1.60 points. Meanwhile, women who have finished elementary, high school, and college education have EPDS-F scores lower by 1.23 points, 2.46 points, and 3.69 points, respectively, compared to women who have no educational attainment. In addition, having a higher level of family income was found to be associated with a lower EPDS-F score.

The same results were found to be robust using the logistic and probit regression approaches. Having an abdominal delivery is correlated with a lower EPDS-F score by $0.87 \%$ using the logistic regression and $0.46 \%$ using the probit regression. Similar to the results from the OLS approach, having a higher level of educational attainment and monthly family income are associated with a lower EPDS-F score. 


\section{DISCUSSION}

The characteristics that were noted to be significant in the development of postpartum depression as determined by the Edinburgh Postnatal Depression Scale-Filipino Translation (EPDS-F) are low educational attainment (below tertiary education, $\mathrm{p}<0.01$ ) and lower family income (below PhP10,000 below family income, $p<0.01$ ). Both are consistent with the Torres studyg.Low family income was also a significant risk factor in an Indian study 18 . Interestingly, abdominal delivery was found to be correlated to a high EPDS-F score ( $p$ $<0.05)$. Previous studies showed no effect of route of delivery on the development of PPD. A meta-analysis in 201719 showed that caesarean section increases the risk for PPD. It is important to note that the rate of abdominal delivery for this study is quite high at $53.3 \%$ (the ideal rate according to the World Health Organization is only $10-15 \% 20)$. This could be attributed to the fact that this study was conducted in a tertiary hospital that caters to more complicated pregnancies, many of which require delivery by caesarean section. In $2016,43 \%$ of deliveries at this hospital were by caesarean section.

Among all of the above characteristics, based on the computed $p$-values and regression analysis, it appears that the ones that proved significant for having a high EPDS-F score are the following: having low educational attainment (below tertiary), having lower family income (less than PhP10,000), vaginal delivery, and use of epidural anesthesia. The finding that those with high EPDSF scores are most likely to have had epidural anesthesia is contradictory to the finding that those with high EPDS scores are most likely to have undergone 
abdominal rather than vaginal delivery, if decreased pain is the supposed rationale. Perhaps there are other factors associated with vaginal delivery that increases the EPDS-F score.

Comparing with the findings of the Torres studyg, the only common risk factors for developing postpartum depression are having low educational attainment and low family income. This can be explained by the growing inflation and the increased poverty rates. Additional factors that are frequently associated with postpartum depression include, stressful life events (e.g., marital conflict or emigration) during pregnancy or after delivery, as well as poor social and financial support in the puerperium21.

\section{LIMITATIONS}

As this is a cross-sectional design, the data is reflective of the prevalence and risk factors of postpartum depression only at the point in time they were obtained. It is recommended that further studies using a cohort design to determine lifetime prevalence of postpartum depression be conducted. Causality cannot be established as well.

\section{CONCLUSIONS}

The Edinburgh Postnatal Depression Scale Filipino Translation (EPDS-F) is a useful screening tool for postpartum patients. It is an ideal tool because it consists of only ten items and is self-administered. 
The prevalence of postpartum depression in this study was found to be $14.5 \%$. The variables that were found to be significant in those who had high EPDS-F scores were monthly family income below $\mathrm{PhP} 10,000$, educational attainment below tertiary, and vaginal delivery.

The higher prevalence noted in this study may be due to risk factors present in the population-such as low socioeconomic status and low educational attainment. It may be worthwhile to compare responses from a public versus a private institution, as well as urban versus rural, non-hospital based areas. It would be interesting also to further evaluate the mode of delivery variable and how exactly it correlates with the development of PPD.

Obstetricians, midwives, and all those who care for pregnant women will do well to remember that the duty to each patient does not end with a safe delivery. It is imperative to ensure her complete physical and mental well-being even in the puerperium and beyond. Screening during a critical period of vulnerability such as in the puerperium will allow early detection, prevention and treatment.

\section{ABBREVIATIONS}

PPD - Postpartum depression

EPDS - Edinburgh Postnatal Depression Scale

EPDS-F - Edinburgh Postnatal Depression Scale-Filipino Translation

OPD - outpatient department

OLS - ordinary least squares 


\section{DECLARATIONS}

\section{Ethics approval and consent to participate}

This study was conducted through survey. All patient information was kept confidential. No data or test result were used for any other purpose other than what it was intended. The study protocol was submitted for ethics review by the University of the Philippines Manila Research Ethics Board (UPMREB), which has the following reference numbers:

UPMREB IRB Registration \#: IRB00002908

IORG \#: IORG0002365 - Expiry: 02/15/2021

FWA \#: 00018728 - Expiry: 04/12/2022

Data collection only ensued upon approval. This study was funded by the primary investigator only. Written consent was obtained from the participants and they were also given copies of the informed consent form. No conflict of interest was identified among the investigators, the patients and the institution.

It is important to note that answering items on the EPDS-F might cause participants to think about feelings of depression, worthlessness, and selfharm. Participants who were classified as at risk for developing PPD based on their EPDS-F score were referred to Psychiatry for further evaluation and management.

\section{Consent for publication}

Not applicable 


\section{Availability of data and materials}

All data generated or analyzed during this study are included in this published article.

\section{Competing interests}

The authors declare that they have no competing interests.

\section{Funding}

This study received no funding. All expenses were shouldered by the primary author

\section{Authors' contributions}

MS was responsible for the conception of the study; the acquisition, analysis, and interpretation of data, as well as drafting and revision of the work.

$\mathrm{MH}$ was likewise responsible for the conception of the study; the acquisition, analysis, and interpretation of data, as well as drafting and revision of the work.

All authors have read and approved the manuscript.

\section{Acknowledgements}

Mr. Jan Christopher G. Ocampo 


\section{REFERENCES}

1. Thurgood S, Avery D, William L. Postpartum depression. American Journal of Clinical Medicine. 2009; 6(2).

2. Kupfer DJ, Regier DA (eds). Diagnostic and Statistical Manual of Mental Disorders, 5th ed. American Psychiatric Association, 2013.

3. De Chavez M, Capco-Dichoso M, Prevalence of postpartum depression among mothers who delivered in a tertiary hospital. Philippine Journal of Obstetrics and Gynecology 2014; 38 (3): 15-21.

4. Defensor-Santiago M. Postpartum depression research act of 2007. Senate Bill No. 2655. 13th Congress.

5. Beck CT. 2001. Predictors of Postpartum Depression: An Update. Nursing Research 50(5): 275-285.

6. Miller LJ. Postpartum Depression. Journal of the American Medical Association. 2002; 287(6):762-765.

7. Cunningham FG, Gant NF, Leveno KJ, Gilstrap III LC, Hauth JC and Wenstrom KD (eds): Williams Obstetrics, 24th ed. USA: McGraw-Hill, 2014.

8. Philipps LH, O'Hara MW. Prospective study of postpartum depression: 41/2year follow-up of women and children. Journal of Abnormal Psychology 1991; 100(2): 151-155.

9. Dennis CL, Hodnett ED. Psychosocial and psychological interventions for treating postpartum depression. Cochrane Database of Systematic Reviews 2007; Issue 4. Art. No.: CD006116. 
10. Screening for perinatal depression. Committee Opinion No. 630. American College of Obstetricians and Gynecologists. Obstet Gynecol 2015;125:1268-71.

11. Nelson DB, Freeman MP, Johnson NL, et al: A prospective study of postpartum depression in 17648 parturients. J Matern Fetal Neonatal Med 2013; 26(12):1156.

12. Cox JL et al. Development of a 10-item Edinburgh Postnatal Depression Scale. British Journal of Psychiatry 1987 (150); 6 (3): 82-87.

13. Torres RF, et al. Validation of the Edinburgh Postnatal Depression Scale (EPDS) among Filipino women. Philippine Journal of Obstetrics and Gynecology 2009; 29 (1): 21-27.

14. Goker A, et al. Postpartum depression: Is mode of delivery a risk factor? ISRN Obstetrics and Gynecology 2012, article ID 61675.

15. Hui Xu, Yu Ding, Yue Ma, Xueling Xin, Dongfeng Zhang. Cesarean section and risk of postpartum depression: A meta-analysis. Journal of Psychosomatic Research, 2017.

16. WHO Statement on Caesarean Section Rates. Department of Reproductive Health and Research, World Health Organization, 2015. 


\section{ADDITIONAL FILES}

\section{APPENDIX A: EDINBURGH POSTNATAL DEPRESSION SCALE (EPDS)}

\section{CODE}

As you have recently had a baby, we would like to know how you are feeling. Please SHADE the answer which comes closest to how you have felt IN THE PAST 7 DAYS, not just how you feel today.

Here is an example, already completed.

I have felt happy:

$\square$ Yes, all the time

Yes, most of the time

$\square$ No, not very often

№, not at all

This would mean: "I have felt happy most of the time" during the past week.

Please complete the other questions in the same way.

In the past 7 days:

1. I have been able to laugh and see the funny side of things

$\square$ As much as I always could

$\square$ Not quite so much now

$\square$ Definitely not so much now

$\square$ Not at all

2. I have looked forward with enjoyment to things

$\square$ As much as I ever did

$\square$ Rather less than I used to

$\square$ Definitely less than I used to

$\square$ Hardly at all

3. I have blamed myself unnecessarily when things went wrong

$\square$ Yes, most of the time

$\square$ Yes, some of the time

$\square$ Not very often

$\square$ No, never

4. I have been anxious or worried for no good reason

$\square$ No, not at all

$\square$ Hardly ever

$\square$ Yes, sometimes

$\square$ Yes, very often

5. I have felt scared or panicky for no very good reason

$\square$ Yes, quite a lot

$\square$ Yes, sometimes

$\square$ No, not much

$\square$ No, not at all

6. Things have been getting on top of me

Yes, most of the times I haven't been able to cope at all 
Yes, sometimes I haven't been coping as well as usual

$\square$ No, most of the time I have coped quite well

$\square$ No, I have been coping as well as ever

7. I have been so unhappy that I have had difficulty sleeping

$\square$ Yes, most of the time

$\square$ Yes, some of the time

$\square$ Not very often

$\square$ No, not at all

8. I have felt sad or miserable

$\square$ Yes, most of the time

$\square$ Yes, some of the time

$\square$ Not very often

$\square$ No, not at all

9. I have been so unhappy that I have been crying

$\square$ Yes, most of the time

$\square$ Yes, some of the time

$\square$ Only occasionally

$\square$ No, never

10. The thought of harming myself has occurred to me

$\square$ Yes, quite often

$\square$ Sometimes

$\square$ Hardly every

$\square$ Never 


\section{APPENDIX B: EDINBURGH POSTNATAL DEPRESSION SCALE-FILIPINO TRANSLATION (EPDS-F)}

\section{CODE}

\section{Kumusta na ang iyong pakiramdam?}

Sa dahilang ikaw ay nanganak kamakailan lamang, nais naming malaman kung ano ang iyong pakiramdam sa ngayon. Mangyari lamang na guhitan ang sagot na pinakamalapit sa iyong naramdaman sa nakaraang 7 araw, hindi lamang ang iyong nararamdaman sa ngayon.

Narito ang isang halimbawa, na nasagutan na:

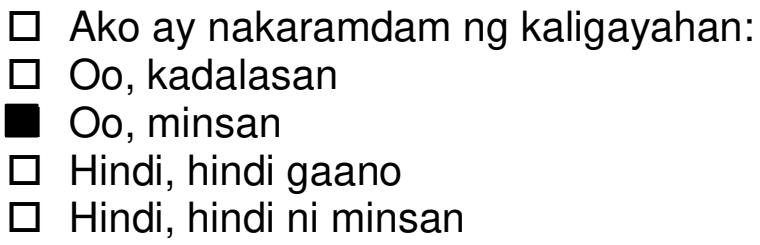

Nangangahulugan ito na: 'Minsan ako ay nakaramdam ng kaligayan sa nakaraang linggo.' Mangyari lamang na kumpletohin ang iba pang mga katanungan sa parehong

paraan.

\section{SA NAKARAANG 7 ARAW:}

1. Nagawa kong tumawa at nakita ko ang nakakatuwang bahagi ng mga bagay:

$\square$ Kasing dalas ng palagi kong ginagawa

$\square$ Hindi na gaano kadalas sa ngayon

$\square$ Talagang hindi na gaano kadalas sa ngayon

Hindi ni minsan

2. Umaasa ako na masisiyahan sa mga bagay:

$\square$ Kasing dalas ng dati kong ginagawa

$\square$ Hindi na gaano kadalas katulad ng dati kong ginagawa

$\square$ Talagang di na gaano kadalas katulad ng dati kong ginagawa

Bibihirang mangyari

3. Sinisi ko ang aking sarili kapag may mga maling bagay na nangyari:

$\square$ Oo, kadalasan

Oo, minsan

$\square$ Hindi gaanong madalas

$\square$ Hindi, hindi kailanman

4. Nag-alala ako o nabalisa nang walang magandang kadahilanan:

$\square$ Hindi, hindi ni minsan

Bibihirang mangyari 
Oo, kung minsan

$\square$ Oo, napakadalas

5. Nakaramdam ako ng takot o biglang pagkatakot nang walang magandang dahilan:

$\square$ Oo, napakadalas

$\square$ Oo, paminsan-minsan

$\square$ Hindi, hindi gaanong madalas

$\square$ Hindi, hindi ni minsan

6. Nahihirapan akong makayanan ang mga bagay:

$\square$ Oo, kadalasan ay hindi ko nakakayanan ang mga bagay

$\square$ Oo, paminsan-minsan ay hindi ko nakakayanan ang mga bagay nang kasing husay ng dati

$\square$ Hindi, kadalasan ay nakayanan ko nang mahusay ang mga bagay

Hindi, nakakayanan ko ang mga bagay katulad ng palagian

7. Naging sobrang malungkutin ako kaya nahirapan ako sa pagtulog:

$\square$ Oo, kadalasan

$\square$ Oo, napakadalas

$\square$ Hindi gaanong madalas

$\square$ Hindi, hindi kailanman

8. Nakaramdam ako ng lungkot at pagiging kahabag-habag:

$\square$ Oo, kadalasan

$\square$ Oo, napakadalas

$\square$ Hindi gaanong madalas

$\square$ Hindi, kailanma'y hindi

9. Naging malungkutin ako na naging dahilan ng aking pag-iyak:

$\square$ Oo, kadalasan

$\square$ Oo, napakadalas

$\square$ Paminsan-minsan lamang

$\square$ Hindi, kailanma'y hindi

10. Ang pag-iisip na saktan ang aking sarili ay nangyari sa akin:

$\square$ Oo, napakadalas

$\square$ Paminsan-minsan

$\square$ Bibihirang mangyari

$\square$ Hindi kailanman 


\section{APPENDIX C: SOCIODEMOGRAPHIC DATA SHEET (FILIPINO)}

CODE:

1. Edad:

2. Estado:
$\square$ Di-kasal
$\square$ Kasal
$\square$ Hiwalay
$\square$ May kinakasama sa bahay
$\square$ Biyuda

3. Natapos na pag-aaral
$\square$ Elementary
$\square$ High school
$\square$ College

4. Nagtatrabaho

Oo (Trabaho:

$\square$ Hindi

5. Suweldo ng pamily kada buwan (Pesos)
$\square<5,000$
$5,000-10,000$
ㄷ $10,000-15,000$
15,000-20,000
$\square \geq 20,000$

6. Nagkaroon ng sakit sa pag-iisip?

$\square$ Oo

$\square$ Hindi

7. May kamag-anak na nagkaroon ng sakit sa pag-iisip?
$\square$ Oo
$\square$ Hindi

8. Kasalukuyang naninigarilyo?
$\square$ Oo
$\square$ Hindi

9. Kasalukuyang umiinom ng alak?

$$
\begin{aligned}
& \square \text { Oo } \\
& \square \text { Hindi }
\end{aligned}
$$

10. Nakaranas ng pisikal na pang-aabuso?
$\square$ Oo
$\square$ Hindi

11. Nakaranas ng sekswal na pang-aabuso?
$\square$ Oo
$\square$ Hindi

12. Estado ng anak?
$\square$ Buhay
$\square$ Namatay

13. Pinlano ang pagbubuntis?

$\square$ Oo 
14. Kasalukuyang nagpapasuso sa anak?

$\square$ Oo

$\square$ Hindi 
APPENDIX D: SOCIODEMOGRAPHIC DATA SHEET - English

15. Age:

16. Marital status
$\square$ Single
$\square$ Married
$\square$ Separated
$\square$ Common-law partner
$\square$ Widowed

17. Educational attainment

$\square$ Elementary school

$\square$ High school

$\square$ College

18. Employment status

$\square$ Employed

$\square$ Unemployed

19. Monthly family income (in Pesos)
$\square<5,000$
ㅁ 5,000-10,000
ㅁ 10,000-15,000
ㄷ 15,000-20,000
$\square \geq 20,000$

20.Previously diagnosed with psychiatric condition?
$\square$ Yes
$\square$ No

21. Family history of psychiatric illness?

$\square$ Yes

$\square$ No

22. Currently smoking?
$\square$ Yes
$\square$ No

23. Currently with alcohol intake?
$\square$ Yes
$\square$ No

24. History of physical abuse
$\square$ Yes
$\square$ No

25. History of sexual abuse?
$\square$ Yes
$\square$ No

26. Status of child?

$\square$ Alive

$\square$ Died

27. Planned pregnancy?
$\square$ Yes
$\square$ No

28. Currently breastfeeding? 
$\square$ Yes
$\square$ No 


\section{APPENDIX E: DATA OBTAINED FROM CHARTS}

1. OB score:

2. With medical comorbidities?

$\square$ Hypertension

$\square$ Diabetes mellitus

$\square$ Heart disease

$\square$ Thyroid disease

$\square$ Others:

3. Mode of delivery

$\square$ Vaginal

$\square$ Abdominal

If vaginal delivery:

a. Induction of labor?

$\square$ Yes

$\square$ No

b. Epidural anesthesia given?

$\square$ Yes

$\square$ No

b. Hours of labor

$\square<8$ hours

$\square \geq 8$ hours

4. Any obstetric complication?

$\square$ Yes (Specify:

$\square$ No

5. Child with congenital illness?

$\square$ Yes

$\square$ No 


\title{
APPENDIX F: INFORMED CONSENT (FILIPINO)
}

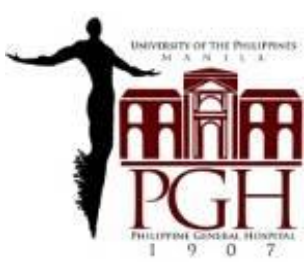

\author{
University of the Philippines \\ College of Medicine \& Philippine General Hospital \\ Department of Obstetrics and Gynecology \\ Taft Avenue, Manila \\ Tel. No. 524-5741/5218450 loc. 2357/ Telefax 632-5241098 \\ Email address: pghobgyn2002@yahoo.com
}

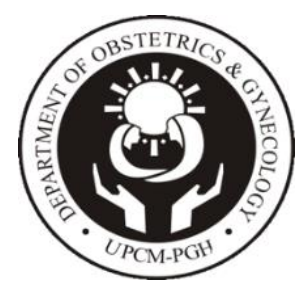

Kaalamang pahintulot para sa mga bagong panganak sa Outpatient Department ng Philippine General Hospital Department of Obstetrics and Gynecology, na inaanyaya naming maging kalahok sa pananaliksik sa postpartum depression o PPD.

Ang pamagat ng pananaliksik na ito ay: Determination of the Prevalence of Postpartum Depression and Risk Factors Among Postpartum Patients at a Tertiary Government Urban Hospital Using the Edinburgh Postnatal Depression Scale

> Pangunahing Imbestigador: Maria Carmina L. Santiago, M.D.

> Tagapatnubay na Imbestigador: Ma. Antoinette Habana, M.D.

$>$ Department of Obstetrics and Gynecology, Philippine General Hospital

Ang Kaalamang Pahintulot na ito ay may dalawang bahagi:

$>$ Impormasyon Tungkol sa Pananaliksik

$>$ Patunay ng Pahintulot

Kayo po ay bibigyan ng kopya ng buong kaalamang pahintulot.

Unang Bahagi: Impormasyon Tungkol sa Pananaliksik

Panimula

Ako po si Dr. Maria Carmina Santiago, residente po ng Department of Obstetrics and Gynecology ng Philippine General Hospital. Ako po ay kasalukuyang may isinasagawang pananaliksik tungkol sa depresyon sa mga bagong kapapanganak o POSTPARTUM DEPRESSION. Bibigyan ko po kayo ng impormasyon tungkol sa pananaliksik na ito at iniimbita ko po kayo maging kalahok. Kung mayroong pong hindi malinaw sa pananaliksik or kung nais ninyo nang karagdagang impormasyon, huwag po kayo mag-alinlangang magtanong.

Layunin ng pananaliksik

Ang depresyon sa mga bagong panganak o POSTPARTUM DEPRESSION (PPD) ay nararanasan ng 10-15\% ng lahat ng bagong panganak na kababaihan. Ang PPD kapag hindi naagapan ay maaring magdulot ng patuloy 
na depression sa ina o kaya problema sa kilos ng kanyang anak. Sa Pilipinas, kaunti pa lamang ang nagagawang pananaliksik tungkol sa kondisyong ito.

\section{Uri ng pananaliksik}

Ang Edinburgh Postnatal Depression Scale (EPDS) ay isang palatanungan na ginagamit upang malaman kung ang isang bagong panganak ay mayroong depresyon. Maari po lamang na sagutan niyo ito pati na rin ang data sheet tungkol sa inyong mga personal na detalye.

\section{Pagpili ng mga kalahok}

Kayo po ay inaanyayahang makilahok sa pag-aaral na ito kasama ng 400 na mga bagong panganak na babae.

\section{Boluntaryong pakikilahok}

Ang pagsali sa pananaliksik na ito ay hindi sapilitan. Kayo ay maaari tumanggi sa pagsali kung nais ninyo. Wala po magiging implikasyong ang pagtanggi niyo sa pakikilahok sa pag-aaral na ito. Makakatanggap pa rin kayo ng lahat ng serbisyo ng pasyente ng ospital na ito kahit piliin niyong hindi maging kalahok.

\section{Paglalarawan ng proseso}

Kayo po ay bibigyan ng dalawang palatanungan:

1. Edinburgh Postnatal Depression Scale (Filipino)

2. Sociodemographic data sheet

Maari po lamang na sagutin ninyo ito habang naghihintay na kayo ay tawagin sa Outpatient Department.

Maari din po na kumuha ng karagdagang impormasyon mula sa inyong tsart.

\section{Mga posibleng panganib}

Ang partisipasyon sa pag-aaral ay maaring magdulot ng mga di kanais-nais na damdamin dahil sa mga sensitibong tanong sa EPDS. Kung sakaling makaranas kayo ng mga ito, maaari po kayong komonsulta sa doktor ng pagiisip o psychiatrist. Lahat po nang gastusin sa pagpapakonsulta at gamutan ay sasagutin ng Pangunahing Imbestigador.

\section{Mga benepisyo}

Ang pakikilahok ninyo sa pag-aaral na ito ay ang magiging napakahalagang kontribusyon sa pananaliksik sa PPD at makakatulong sa lahat ng kababaihang nakararanas at makakaranas pa nito. Bukod doon, ang pagsagot sa EPDS ay magsisilbing pagsuri kung mayroong PPD. At kung natuklasan na mayroong PPD, maagapan kaagad sa pamamagitan ng pagkonsulta sa espesyalista.

\section{Kompensasyon}

Walang dagdag na gastusin ang inaasahan sa inyo sa pagiging kalahok ninyo sa pag-aaral na ito. Wala rin kayong matatanggap na kabayaran o kompensasyon. 


\section{Kompidensyalidad}

Ang lahat ng impormasyong makokolekta sa pananaliksik na ito ay magiging lihim 0 kompidensyal. Tanging ang mga imbestigador lamang ang makakahawak ng impormasyong ito. Ang impormasyon tungkol sa inyo ay itatago sa isang numero at hindi gamit ang inyong pangalan.

Pagbabahagi ng resulta

Maari po kayong makahingi ng kopya ng resulta ng pananaliksik na ito bago pa man mailabas sa publiko. Posible pong mailabas sa mga opisyal na pahayagan ang mga resulta ng pananaliksik na ito. Ang kompidensiyal na impormasyon ay hindi po ilalabas.

Karapatang tumanggi o bawiin ang pahintulot

Ang pakikilahok ninyo sa pananaliksik na ito ay boluntaryo at hindi sapilitan. Maari ninyong bawiin ang inyong pagsali sa kahit anong punto ng pananaliksik. Hindi po maapektuhan ang mga serbisyong matatanggap ninyo bilang pasyente ng institusyong ito.

\section{Pakikipag-ugnayan}

Kung kayo ay mayroong mga katanungan maaari po kayo magtanong ngayon o sa susunod kahit pagkatapos ninyo sagutin ang palatanungan. Kung may mga katanungan kayo sa susunod, maaari po kayo makipagugnayan sa mga sumusunod:

Pangunahing Imbestigador:

Dr. Maria Carmina L. Santiago

09189054618

mindy.santiago@gmail.com

Tagapatnubay na Imbestigador:

Dr. Maria Antonia E. Habana

09178965778

aehabana@yahoo.com

Ang pag-aaral na ito ay inaprubahan ng University of the Philippines Manila Research Ethics Board (UPMREB) Panel, na ang tungkulin ay tumangkilik sa mga karapatan ng mga kalahok sa pananaliksik. Kung mayroon kayong mga katanungan tungkol sa UPMREB Panel, pakikontak si:

Dr. Doris R. Benavides

UPMREB Panel 3 Chair

Address: National Institutes of Health

547 Pedro Gil St

Ermita 1000 Manila

Email: upmreb@post.upm.edu.ph

Tel: +6325264346 
Mobile: 0917-621-3630

Ikalawang bahagi: Patunay ng Pahintulot

Nabasa ko ang impormasyon sa ibabaw o naibasa siya sa akin. Nakapagtanong na ako at nasagot nang sapat ang aking mga katanungan. Pumapayag akong maging kalahok sa pananaliksik na ito.

Buong pangalan ng kalahok

Lagda ng kalahok

Petsa

Araw/buwan/taon

Kapag hindi nakakabasa o nakakasulat ang kalahok:

Ako ay naging saksi ng tamang pagbasa ng kaalamang pahintulot sa posibleng kalahok. Nabigyan siya ng pagkakataong magtanong. Pinapatunayan ko na kusang nagbigay siya ng kanyang pagsang-ayon sa pakikilahok.

Pangalan ng saksi AT Bakas-daliri ng hinlalaking kalahok

Lagda ng saksi

Petsa

Araw/buwan/taon

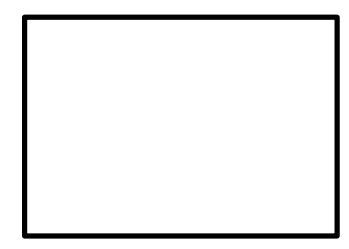

Pahayag ng Imbestigador/tagakuha ng pahintulot

Naibasa ko nang tama ang mga impormasyon sa posibleng kalahok at, sa lubos ng aking kakayanan, sinigurado na naintindihan ng kalahok na:

1. Sasagutan niya ang Edinburgh Postnatal Depression Scale (Filipino)

2. Sasagutan niya ang sociodemographic questionnaire

3. Maaring kumuha ng karagdagang impormasyon mula sa kanyang tsart

Pinapatunayan kong nabigyan ng sapat na pagkakataong magtanong tungkol sa pananaliksik, at lahat ng kanyang katanungan ay nasagot sa lubos ng aking kakayanan. Pinapatunayan ko na mwalang sapilitang naganap upang makuha ang pahintulot ng kalahok. Ang kalahok ang kusang nagbigay ng kanyang pahintulot. 
Ang kalahok ay nabigyan ng kopya ng kaalamang pahintulot na ito.

Pangalan ng Imbestigador/tagakuha ng pahintulot

\begin{tabular}{llll}
\hline Lagda & ng & Imbestigador/tagakuha
\end{tabular}
pahintulot

Petsa

Araw/buwan/taon 


\title{
APPENDIX G: INFORMED CONSENT (ENGLISH)
}

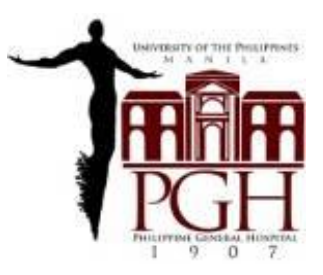

\author{
University of the Philippines \\ College of Medicine \& Philippine General Hospital \\ Department of Obstetrics and Gynecology
}

Taft Avenue, Manila

Tel. No. 524-5741/5218450 loc. 2357/ Telefax 632-5241098

Email address: pghobgyn2002@yahoo.com

PHIC - Accredited Health Care Provider

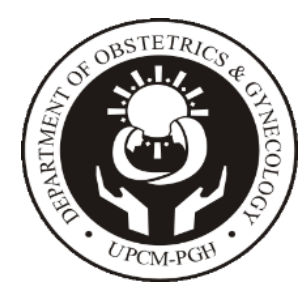

Informed Consent form for postpartum women on follow up at the Outpatient Department of the Philippine General Hospital Department of Obstetrics and Gynecology, whom we are inviting to participate in research on postpartum depression. The title of this research project is Determination of the Prevalence of Postpartum Depression and Risk Factors Among Postpartum Patients at a Tertiary Government Urban Hospital Using the Edinburgh Postnatal Depression Scale]

$>$ Principal Investigator: Maria Carmina L. Santiago, M.D.

$>$ Supervising investigators: Ma. Antoinette Habana, M.D.

$>$ Department of Obstetrics and Gynecology

This Informed Consent Form has two parts:

$>$ Information Sheet (to share information about the research with you)

$>$ Certificate of Consent (for signatures if you agree to take part)

You will be given a copy of the full Informed Consent Form.

\section{PART I: Information Sheet}

\section{Introduction}

I am Dr. Maria Carmina Santiago, a resident of the Department of Obstetrics and Gynecology of the Philippine General Hospital. I am currently conducting research on postpartum depression (PPD). I will give you information on this research and invite you to participate. You do not have to decide today whether or not you will participate in the research. Before you decide, you can talk to anyone you feel comfortable with about the research.

There may be some words that you do not understand. Please ask me to stop as we go through the information and I will take time to explain. If you have questions later, you can ask them of me.

\section{Purpose of the research}

Postpartum depression occurs in $10-15 \%$ of all deliveries. However very little research has been done on the development and prevention of this disorder in the Philippines. It is the goal of this research to establish the prevalence of PPD among Filipina women and evaluate the possible risk factors for its development.

Type of Research Intervention 
The Edinburgh Postnatal Depression Scale (EPDS) is a 10-item questionnaire used to identify women who have postpartum depression. It consists of a ten-item self-report scale. You will be asked to answer this questionnaire along with a personal data sheet.

\section{Participant selection}

We are inviting you, along with 400 other postpartum women, to participate in this research on postpartum depression.

\section{Voluntary Participation}

Your participation in this research is entirely voluntary. It is your choice whether to participate or not. Whether you choose to participate or not, all the services you receive at this institution will continue and nothing will change. You may change your mind later and stop participating even if you agreed earlier.

\section{B. Description of the Process}

You will be given two forms to fill up:

1. The Edinburgh Postnatal Depression Scale (translated in Filipino)

2. Sociodemographic data sheet.

You can accomplish these two sheets while waiting for your turn at the Outpatient Department.

We are also requesting your permission to access additional data in your hospital chart.

\section{Risks}

Your participation in this research may evoke negative emotions due to the sensitive nature of the questions in the EDPS. If you do develop any of these, please let us know right away and we can arrange for proper counseling with a psychiatrist. Rest assured that any and all expenses incurred for consultation and/or treatment will be shouldered by the Primary Investigator.

\section{Benefits}

You participation in this research will benefit those currently suffering from postpartum depression as well as future generations of women who are at risk for developing PPD.

\section{Reimbursement}

You will not be asked to spend for anything for this study. Likewise, you will also not receive any compensation for your participation.

\section{Confidentiality}

The information that we collect from this research project will be kept confidential. Information about you that will be collected during the research will be put away and no one but the researchers will be able to see it. Any information about you will have a number on it instead of your name. Only the researchers will know what your number is and we will lock that information up with a lock and key. It will not be shared with or given to anyone except the UPMREB.

\section{Sharing the Results}

The knowledge that we get from doing this research may be available to you if you are interested. Confidential information will not be shared. It is hoped that the results be published in order that other interested people may learn from our research.

\section{Right to Refuse or Withdraw}


You do not have to take part in this research if you do not wish to do so and refusing to participate will not affect your treatment at this institution in any way. You will still have all the benefits that you would otherwise have at this institution. You may stop participating in the research at any time that you wish without losing any of your rights as a patient here. Your treatment at this institution will not be affected in any way.

Who to Contact

If you have any questions you may ask them now or later, even after the study has started. If you wish to ask questions later, you may contact the Primary Investigator:

Dr. Maria Carmina L. Santiago

09189054618

mindy.santiago@gmail.com

This proposal has been reviewed and approved by the University of the Philippines Manila Research Ethics Board (UPMREB) Panel, a committee whose task is to make sure that research participants are protected from harm. If you wish to find more about the UPMREB Panel, you may call the UPMREB at 5548400 local 2065, Monday thru Thursday, 8:00AM-4:00PM, located at the 2nd Floor Main Administrative Building, Philippine General Hospital, Taft, Manila.

PART II: Certificate of Consent

I have read the foregoing information, or it has been read to me. I have had the opportunity to ask questions about it and any questions that I have asked have been answered to my satisfaction. I consent voluntarily to participate as a participant in this research.

Print Name of Participant

Signature of Participant

Date

Day/month/year

If cannot read and/or write

I have witnessed the accurate reading of the consent form to the potential participant, and the individual has had the opportunity to ask questions. I confirm that the individual has given consent freely.

Print name of witness

AND Thumb print of

participant

Signature of witness

Date

Day/month/year

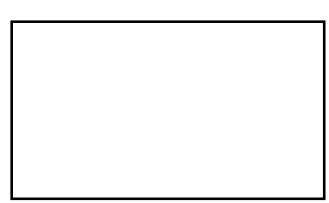

Statement by the researcher/person taking consent

I have accurately read out the information sheet to the potential participant, and to the best of my ability made sure that the participant understands that the following will be done:

1. Accomplishment of the Edinburgh Postnatal Depression Scale (Filipino) 
2. Accomplishment of the sociodemographic questionnaire

3. Data from the participant's hospital chart can be accessed

I confirm that the participant was given an opportunity to ask questions about the study, and all the questions asked by the participant have been answered correctly and to the best of my ability. I confirm that the individual has not been coerced into giving consent, and the consent has been given freely and voluntarily.

A copy of this ICF has been provided to the participant.

Print Name of Researcher/person taking the consent

Signature of Researcher /person taking the consent

Date

Day/month/year 


\section{Supplementary Files}

This is a list of supplementary files associated with this preprint. Click to download.

- EdinburghPostnatalDepressionScaleEnglish.pdf

- Strobechecklistforcrosssectionalstudies.pdf 